\title{
THE POLITICAL VOICE OF DIASPORA: AN ANALYSIS OF EXTERNAL VOTING OF MOLDOVAN MIGRANTS
}

\author{
Alla Rosca \\ Edgewater Research LLC, New Orleans, LA
}

\begin{abstract}
The study examines the voting preferences of Moldovan diaspora in the 2014 parliamentary elections. The paper aims to determine which political or economic circumstances in the host country have the biggest impact on determining voting preferences of the migrants. The political favorites of the Moldovan diaspora differ from those of their domestic counterparts. Furthermore, there are essential differences in voting patterns among migrants living in different countries. The findings suggest the migrants' voting behavior is affected in some way by the political and economic realities of the host countries. The voting preferences of voters of the left and right wing parties are mostly affected by the political and socio-economic realities of the country of residence, although members of the diaspora voting for centrist parties are not affected by those factors.
\end{abstract}

Keywords: Diaspora, Migration, Voting, Election, Political resocialization, Moldova.

DOI: http://dx.doi.org/10.15549/jeecar.v6i1.247

\section{INTRODUCTION}

How do diaspora members formulate their voting preferences when participating in the voting process in their country of origin? This research question is explained by the rational choice theory of voting behavior (Downs 1957), that voters preferences are based on voter' utility function, in other words, on their concern of individual economic well-being, and as well, ethnic, political and ideological identification. (Nannestad \& Paldam, 1994). The literature on voting behavior and socialization process also focuses on finding answer to the voter's preferences. (Almond, 1960; Homans 1961; Elster, 1991). Learning of political culture (Almond, 1960) and social interaction (Elster, 1991), most members of the society generally tend to internalize the social values of the given society. (Harsanyi, 1969).
However, the case of diaspora differ from the general population, as migrants are moving to different country, where the social-economic and political environment can be quite different from their country of birth, and the political realities in their original country are not affecting them directly. Although, the research of the diaspora voting preferences often focuses on the political preferences of the migrants voting in the countries of residence, in the societies with long democratic traditions, particularly in the US. (Black, 1987; Cho, 1999; Wong, 2000; Neimi \& Barcan, 1987; Ramakrishan \& Espenshade, 2001).

The new generation of research, featuring the migration from post-1980 democracies emphases different 'diaspora channels' of political influence back home. The literature examines the socioeconomic and political channels, as the weight of remittances, geographic proximity, overseas party presence 
and legislative representation (Burgers, 2014). Given those channels of political influence back home, how are diaspora members formulating their voting preferences? Are the political, economic, and institutional characteristics of their host countries influence the voting preferences? If so, which determinants are the most influential?

The paper examines the re-socialization of migrants, and analyses whether the new political and economic environment influences the voting preferences of diaspora. Specifically, the article formulates two hypotheses: First, the political realms of the host country, as political freedom, civil liberties and political rights, as well as political system and orientation of the government are influencing the voting preferences of diaspora. Second, the economic experiences, as economic freedom and finally, the economic development are inducing the voting preferences of migrants.

To test those hypotheses, the study integrates a number of political, institutional, and economic indicators of the host counties, there the Moldovan diaspora resides. The selection of the case study of the 2014 Parliamentary elections in Moldova was chosen as Moldovan diaspora is spread out across different parts of the world, in different societies, with different, quite opposite political and socio-economic values. Moldovan citizens migrated to the former Soviet Union states, preponderantly to Russia Federation, but also to the Western democratic countries of European Union, as well as to the United States and Canada, to name a few points of destination. The data used in this study, therefore, are akin to a natural experiment, whereby analyzing the voting preferences of migrants from the same country - Moldova - to the Former Soviet Union, as well as to the European and American countries. The early studies concentrated on the diaspora from Central and Eastern Europe (Fidrmuc \& Doyle 2004), and never before on the countries from the Former Soviet Union.

\section{THE LITERATURE REVIEW: THEORIES OF EXTERNAL VOTING}

The question of voting preferences is analyzed by the rational choice theory of voting behavior (Downs 1957). Voters preferences are based on voter utility function, in other words, their concern of their individual economic well-being, and ethnic, political and ideological identification (Nannestad and Paldam, 1994). The literature explains that voter's preferences are based on the factors that determine preferences of votes in general, differentiating between the economic and political components of votes' utility function. The economic component stands for the voter's economic well-being, including the own individual well-being, and general better economic outcome. That is, the voter will prefer a party that will have greater impact on his/her financial utility, if the party eventually participates in the government. The political components of voters' preferences derive from ideology, religion, national, ethnic and linguistic identification.

The literature on political socialization, the decision-making, ideology preferences, and voting behavior addresses the question of political preferences as well. The socialization process includes active learning of political culture, a personal identification with the political world, and becoming aware of values, ideas of the given society, as Almond described it (Almond, 1960). Socialization is a large process through which people gain an understanding of the political world through their interaction with political and governmental institutions, political parties and social leaders, non-governmental institutions, schools, mass media as well as family, peers and colleagues (Conover, 1991).

Resources such as time, prestige, and approval by peers are social rewards that motivate people to act in particular way. Through social interaction people reinforce or undermine certain behaviors through an exchange of rewards and sanctions. As George Homans concluded, the social decisions and actions may be rationally calculated to maximize benefits, and such decisions and actions are oriented to emphasize the importance of mutually interactive performances (Homans 1961). People reinforce or undermine certain behavior through social interactions, and in this way the social order is maintained (Elster, 1991).

Political participation is an imminent part of political behavior, as citizens evaluate their 
satisfaction with democracy and they decide to go one step further and take action, participating in voting process. One of the rationalizations of political behavior, as social behavior, can be determined by the conformist approach and individual behavior, that's it, is based on the assumption that the individual behavior in a given society can be understood in terms of certain commonly accepted social values (Harsanyi, 1969). Most members of the societies generally tend to internalize the social values of the given society, and this practice is the core of their socialization process. Political learning continues over a person's lifetime, and can be developed further in context of changing social and political environment (Hahn 1998; Niemi and Hepburn 1995). Ultimately, the attitudes and preferences can change with the variation of the political and institutional environment.

While the changes of political system and institutions renovations after the dissolution of Soviet Union were profound, the changes experienced by migrant voters are more dramatic. The migrant voters, if they emigrate to the Western countries, are exposed to a considerably different political, cultural, and socio-economic environment. Their worldview therefore has the greatest chance of changing when exposed to a drastically different environment than the one they grew up in. Migrating in more liberal countries, individuals have the opportunities to politically participate in their host countries and are exposed to the real democratic process in action. This is especially veridical regarding the liberal countries of the European Union and North America. There is empirical evidence that even a brief exposure to the U.S. political institutions and life helps migrants socialize, and their views of democracy are becoming closer to those of the Americans in the United States than that of their home country (Camp, 2003; Garza \& Yetim 2003).

The normatively more desirable situation makes not so difficult to switch modes of political preferences. Democratic liberties fulfill an essential desire for freedom, and political equality satisfies a need for recognition before one's peers. Experiencing the political and social benefits of a more democratic society could make the migrants reluctant to settle for anything less. The experiences acquired in the less democratic countries as their own, are also influencing individuals who are migrated there. But the experience has other character, meaning restrictions in the social and political life, reduced opportunities to freely participate in the social movements, public protests and marches, as well in the assemblies and rallies. Political socialization also takes place, but in different political environments.

The political behavior of migrants, and particularly voting preferences, depends of their age, political learning, of time they are being exposed to the new social environment, and political activities in the new societies (Cho, 1999; Wong, 2000). Studies of voting behavior of migrants are primarily from the democratic societies, especially in the United States (Black 1987). The literature examines the new sociopolitical environment, that constitutes a propitious condition for the reinforcement of the existing ideas and beliefs and constitutes a factor for the migrant' resocialization (Glaser 1997).

The resocialization theory focuses, among other elements, on exposure, or how much exposure immigrants have to the new host country's political system: the more exposure they have, the more they adapt (Arvizu \& Garcia, 1996; Ramakrishan \& Espenshade, 2001). The studies are considering the effects of the political exposure and the voter turnout (Neimi \& Barcan, 1987) and partisanship (Neimi at all 1985), as well as the age group of the immigrants. Although, those findings refer, mostly, to the migrants voting in the new host countries, and not to the political participation of the diaspora in the elections in their country of origin.

With the introduction of the concept of immigrants' transnationalism (OstergaardNielsen, 2017), scholars increasingly looked at the political connections of immigrants with the countries of origin. As a result, a new line of research has developed regarding the right of citizens residing abroad to vote in home country elections i.e. external voting. It is in this framework that the extension of the formal political rights, such as the rights to vote in home country for the diaspora community are 
examined (Baudock 2007). The predominant research questions addressed are regarding the conditions that lead the sending states to enfranchise citizens abroad and why an increased number of states are doing that. Also, the impact of the emigrant voters on the electoral and political process in the home countries are studied, and particularly the diffusion of the democracy and contribution to the democratic process at home (Rhodes \& Hatutyunyan, 2010; Lafleur, 2011; Collyer, 2014; Turku, 2015). Though, the studies did not examine the dichotomy of diaspora from the Former Soviet States living in different socioeconomic and political societies, as the former Soviet Union states and Western countries, with possibility to associate the social-economic and political environment in those countries with the voting preferences of diaspora.

\section{METHODOLOGY}

The major variable of interest in this analysis is the proportion of votes that winning parties received in the Moldovan parliamentary elections 2014 from voters living in certain countries. The analysis utilizes official information of votes cast by Moldovan citizen in 31 countries for the parliamentary elections of 2014.

To test the migrant voter's behavior the research formulates the hypotheses of the resocialization of migrants, as the members of diaspora living in certain countries are exposed to the political and socio-economic reality of that society. The process of learning and assimilating of social values and ideas are assumed to take place, and consequently, to have an impact on the voting behavior of Moldovan diaspora. The research structure was adapted after Fidrmuc and Doyle (2006) and adjusted to the current research goals.

The dependent variable is the number of votes cast in different countries in the Moldovan 2014 parliamentary elections. Independent variables include the indicators of political and economic characteristics of the countries of residence of Moldovan diaspora. The nature of political environment was measured by the variables of political system and orientation of the government. The analysis included, as well, the indicators of economic freedom, as reported by the Heritage Foundation Economic Freedom and the economic development indicators.

The study includes a number of political and institutional indicators of the countries, where the Moldovan diaspora cast their votes. These include the measure of Democracy of each country, the indexes of Political Freedom, indexes of Civil Liberties and Political Freedom, completed and reported by the Freedom House during the electoral years. The Freedom Index was coded as: 1- free; 2 - partially free; 3 - not free. The Civil Liberties, as well as political rights are coded as: 1- the most free to 7- least free. The study includes also measures of Political Environment as captured by the Database of Political Institutions, and updated by the author. The indicators are the Political System, and coded as: 0 - presidential; 1-assambly elected president; 2-parliamentary, 3-communist state; and Political Orientation of the Government and coded as: 1-right; 2-center; 3-left; 0-no info; NA-no executive.

Next, the measures of Economic Freedom were included as reported by the Heritage Foundation Economic Freedom. Those indicators are coded as: free 80-100; mostly free - 70.079.9; moderately free $-60.0-69.9 ;$ mostly not free - 50.0-59.9; repressed - 0-49.9. The research includes the Eraser Economic Freedom' sub-indexes as: Size of the Government: Expenditure, Taxes and Enterprise, Legal Structure and Security of Property Rights, Access to Sound Money, Freedom to Exchange with Foreigners, Regulation of Credit, Labor and Business. And finally, the measures of economic development included GDP per capita, calculated in current US\$ as of 2014 and 2016; GDP growth and the rate of Inflation for year 2014 (Appendix, List of Explanatory Variables).

The analysis was implemented using a basic ordinary least squares regression (OLS). In order to determine whether any of the variables were correlated, a pairwise comparison of all variables was performed. As a result of the strong correlation between civil liberties, political rights and freedom, each variable was placed in a separate regression. Consecutively, this paper examines the impact of three different sets of variables on the likelihood of a member of the diaspora voting for each respective party. The respective results of the 
linear regressions are show in the tables below.

\section{MOLDOVAN DIASPORA VOTING FRAMEWORK}

The legal framework regulating the voting of Moldovan citizen living abroad is changing, but since becoming an independent state, the Republic of Moldova has allowed the nationals living abroad to participate in the electoral process at home. In the theoretical literature three main variables are identified in explaining why states enfranchise their citizens abroad: a) emigrant lobbying; b) economic dependence on emigration; and c) "domestic politics" (Lafleur, 2011).

Moldovan diaspora is a new post-Soviet Union phenomenon, and diaspora were not well consolidated to lobbying for their voting rights until recently. For the Moldovan case the second and third characteristics are more relevant: Moldovan migrants are economically supporting families at home, and political parties from Moldova are interested in migrants' votes. Moldova is among the world's top remittances countries, migrant workers contributing to about $22 \%$ of the GDP (UN). Along with this, political parties have recently started to pay more attention to build further support from citizens established abroad.

The Constitution and the Legislative Code provide for the Moldovan citizens living abroad the right to vote by registering in advance. The voting is allowed only in person; therefore, voting on-line, by postal ballot or proxy is not possible. The polling stations can be not only at the embassies and consulates, but also other places as well, determined with the mutual accord with the host country. For the 2014 parliamentary election, there were 95 polling stations open abroad, and for the 2016 presidential elections the number was increased to 100. Overall, in 2014 Moldovans cast their votes in 31 different countries, and in 2016 in 33 countries.

The number of votes from abroad had increased in the next consecutive elections, and the votes from abroad accounted for 4.48 percent in the 2014 parliamentary elections, and 8.64 percent in the final round of the 2016 presidential elections. While this can simply reflect the increased number of Moldovans living abroad and the increased number of polling stations, it is undoubtedly also due to the greater mobilization of members of diaspora for the 2016 presidential elections.

\section{THE RESULTS OF 2014 PARLIAMENTARY ELECTIONS}

Moldova's 2014 parliamentary elections were held on November 30, by party-list proportional representation in a single nationwide constituency. In 2014 elections the main dividing line between the parties was foreign policy issue, setting the pro-European Union parties (the Democratic Party (PD), the Liberal Democratic Party of Moldova (PLDM) and Liberal Party (PL)) against those supporting the Russian Federation - Party of Socialists of Moldova (PSM) and Party of Communists of Moldova (PCM).

While there were a large number of register parties that represent Moldovan political landscape, the predominant parties distribution on the left-center-right axis is presented below. On the extreme left, the most radical was the Party of Socialists of Moldova (PSM), which openly supported politico-economic ties with Russia. And on the right was Liberal Party (PL), which openly advocated for the reunification with Romania.

\section{$\begin{array}{lll}\text { LEFT } & \text { CENTER } & \text { RIGHT }\end{array}$}

\begin{tabular}{lllll}
\hline PSM & PCM & PDM & PLDM & PL
\end{tabular}

Table 1 shows the percentages of votes received by the main political parties in the Republic of Moldova 2014 parliamentary elections from votes in the country and those living abroad. The biggest difference is between the two sets of results in the support for the Party of Socialists of Moldova (PSM), which received $20.51 \%$ of the overall vote, and only 
$6.79 \%$ from Moldovan citizen living abroad. While the support for the PSM is much lower among migrant voters, there is considerable variation across the different countries. The Socialists did well in the former Soviet Union countries, were they polled more than the overall results with $24.69 \%$, and in Middle East they scored almost like the overall results of $18.53 \%$. In contrast, they did poorly in European countries with only $2.86 \%$, and in America with only $4.12 \%$.
The other left-wing party, Party of Communists of Moldova (PCM) also received lower support from diaspora - 4.5 Percent, in comparison with the overall result of 17 Percent. Among those results from abroad, the most support came from the former Soviet Union states - 8.4 Percent and Middle East countries - 10.84 Percent. Moldovan citizens living in European countries and America showed considerable lower support (3.35\% and $3 \%$ ) as the overall endorsement of this party.

Table 1 . The results of the Moldova parliamentary election of 2014

\begin{tabular}{|l|r|r|r|r|c|c|r|}
\hline Political Parties & PDM & PLDM & PSM & PCM & PL & Others & No. Of Votes \\
\hline & \multicolumn{1}{c|}{$\%$} & \multicolumn{1}{c|}{$\%$} & \multicolumn{1}{c|}{$\%$} & \multicolumn{1}{c|}{$\%$} & $\%$ & $\%$ & \\
\hline Overall Results $^{1}$ & 16 & 20.16 & 20.51 & 17 & 9.67 & 16.38 & $1,598,518$ \\
\hline Results from Abroad & 9.29 & 33.92 & 6.79 & 4.56 & 20.9 & 24.55 & 71639 \\
\hline Former Soviet Union & 1.81 & 3.38 & 24.69 & 8.43 & 1.32 & 60.37 & 9619 \\
\hline Europe & 9.24 & 38.81 & 2.86 & 3.25 & 27.35 & 18.49 & 31897 \\
\hline Asia & 4.76 & 57.14 & 0 & 0 & 9.52 & 28.57 & 21 \\
\hline Middle East & 7.94 & 20.69 & 18.53 & 10.84 & 7.51 & 34.48 & 1624 \\
\hline America & 4.53 & 37.26 & 4.12 & 3 & 33.06 & 18.02 & 4195 \\
\hline
\end{tabular}

Notes: The party acronyms stand for Democratic Party of Moldova/Partidul Democrat din Moldova (PDM); Liberal Democratic Party of Moldova/Partidul Liberal Democrat din Moldova (PLDM); Party of Socialist of Moldova/Partidul Socialiștilor din Moldova (PSM); Party of Communists of Moldova/ Partidul Comuniștilor din Moldova (PCM); Liberal Party/ Partidul Liberal (PL).

${ }^{1}$ Includes votes from abroad

Source: Composed by author from The results of the 2014 Parliamentary Elections in the Republic of Moldova. Central Election Commission. http://www.cec.md/index.php?pag=news\&id=1548\&l=ro. Last accessed November 2, 2017.

The domestic and the migrant votes display the big discrepancies also for the center-right Liberal Democratic Party of Moldova. The PLDM got greater endorsement from abroad - 33.92\% as the overall support - $20.16 \%$. Considerable support from abroad for the PLDM makes it the "winner" of the parliamentary election in terms of abroad votes. But again, there is considerable variation in endorsement of the PLDM of the votes cast abroad, running as high as $57.14 \%$ from Asian countries; 38.81\% from the European countries; $37.26 \%$ from America and 20.69\%
Middle East countries. Only the Moldovans from the former Soviet States showed low support for the PLDM, casting only $3.38 \%$ of votes for this party.

The votes for the center-right Democratic Party of Moldova (PDM) vary from the overall results $-16 \%$ to the diaspora vote $-9.23 \%$. The endorsement from abroad came in lower numbers than the overall support. The PDM gained some support from the Moldovan diaspora living in Europe - 9.24\% and Middle East $-7.94 \%$. At the lower level of votes came 
from America - 4.53\%, Asia - 4.76\% and former Soviet Union - $1.81 \%$.

The overall support from abroad is also higher for the right-wing Liberal Party (PL) at the 20.9\% comparing with the total $9.67 \%$. Support for the LP reaches a high of $33.06 \%$ in America and a low of $1.32 \%$ in former Soviet Union countries. The Liberal Party also gained support from the voters living in Europe (27.35\%), Asia (9.52\%) and Middle East (7.51\%). As the Liberal Party advocates for the reintegration of Moldova with Romania, it's noteworthy to analyze how Moldovans living in Romania voted for this party. The results show that 23 percent of support from abroad for the PL came from the Moldovan diaspora living in Romania, with 3,436 Moldovan migrants voting for this party.

Finally, the penultimate table column shows the percentage of votes received by various small parties, alliances and independent candidates that did not pass the threshold for representation ( $6 \%$ for political parties, $9 \%$ for the alliances of two parties, $11 \%$ for the alliances of 3 and more parties and 2\% for independent candidates). In 2014 parliamentary election of Moldova 16.38 percent of the overall vote went for those parties, alliances and independent candidates, while votes from abroad voted for them in larger number (24.55\%). While showing difference in the results from different countries, all the numbers from abroad are higher in comparison with overall vote.

Those results from Moldova differ from the other research results, for example Czech and Polish migrant voting behavior, where the diaspora was more decisive and voted in lesser numbers for small parties. The explanations given there were that the citizen living abroad might not have received the information about small parties. Alternatively, the hypothesis was that given that the cost of voting is higher for the citizen living abroad they tend to vote for the parties which will enter the parliament and are not inclined to waste their vote by voting for parties which are unlikely to enter parliament (Fidrmuc and Doyle 2004). This is the opposite from the results of the 2014 parliamentary elections in the Republic of Moldova. The Moldovans living abroad were more inclined to vote for the small parties, coalitions and independent candidates as the overall vote. This can be explained that the major political parties did not get support from Moldovan citizen from abroad because the corruption scandals and the high distrust in major political leaders.

Although the 2014 parliamentary elections were assessed as being broadly focused on the geopolitical issues (OSCE), such as engagement with the European Union and the Eurasian Customs Union, the support for the major parties advocating for those orientations were not the only reason explaining the voting choices of diaspora. Also, members of diaspora did not vote only for the well-known and obvious leaders in the electoral race. For example, the Moldovan diaspora from Russian Federation and the former Soviet states voted in bigger numbers for the new Coalition Block "The Choice of Moldova - Customer Union", as they voted for the Party of Socialists, who was the obvious leader. The Coalition Block "The Choice of Moldova - Customer Union" did not past the electoral threshold, but the Party of Socialists of Moldova gained the most seats (25 out of 101) in the Moldova Parliament after the elections. Not the major parties, but other new and small parties received about 60.37 percent of vote from the diaspora in Russian Federation and in former Soviet States. Those examples illustrate that political party "The Choice of Moldova Customer Union" used efficiently a copycat strategy, and Moldovans in Russia, not well informed, assumed that they voted for the major pro-Russian, pro-Customer Union party.

Overall, the results display a great deal of variation in the voting behavior of Moldovan electorate at large and the Moldovan citizens living abroad in the 2014 parliamentary elections. Moldovans living abroad voted for a center-right Parliament (54\%): PLDM - 33.9\% and $\mathrm{PL}-20.1 \%$. The left-wing parties received much less support from the Moldovan electorate living abroad. Although, there are considerable discrepancies among the voting preferences of diaspora members living in different countries. Moldovans living in former Soviet Union countries favored left-wing parties, with support for the PSM being highest, and also the PCM. In contrast, those residing in Western democracies supported more centrist-right and right-wing parties such as PLDM and PL. Moldovans living in Asian countries showed 
more support for the centrist-right and right wing parties, while those living in Middle East had mixed voting preferences.

\section{THE RESULTS OF THE PRESIDENTIAL ELECTIONS OF 2016}

The 2016 direct presidential elections were the results of the Constitutional Court decision for elections to take place on October 30, 2016. The run-off was on November 13, 2016 between two candidates: the leader of the Party of Socialists of Moldova (PSM), Igor Dodon, and the leader of newly created center-right Party of Action and Solidarity (PAS), Maia Sandu.
Socialist leader Igor Dodon actively advocated for closer relations with Russian Federation and Maia Sandu was a liberal, pro-EU candidate.

Table 2 shows the percentage of votes received by the two run-off candidates in the 2016 presidential campaign in the Republic of Moldova. The comparative analysis of the overall vote and the vote from abroad show that preferences differ. The election went to Igor Dodon by a small margin - $52.11 \%$ to $47.89 \%$. However, the Moldovans living abroad preferred Maia Sandu by an overwhelming majority of 86.18 percent.

Table 2. The results of the Moldovan presidential elections of 2016

\begin{tabular}{|l|l|l|}
\hline Presidential candidates & Igor Dodon & Maia Sandu \\
\hline & $\%$ & $\%$ \\
\hline Overall Results $^{1}$ & 52.11 & 47.89 \\
\hline Results from Abroad & 13.82 & $\mathbf{8 6 . 1 8}$ \\
\hline Former Soviet Union & 85.91 & 14.09 \\
\hline Europe & 7.57 & 92.43 \\
\hline Asia & 14.29 & 85.71 \\
\hline Middle East & 40.68 & 59.32 \\
\hline America & 7.18 & 92.82 \\
\hline
\end{tabular}

${ }^{1}$ Includes votes from abroad

Although, the results show considerable divergences in voting patterns of Moldovans living abroad. Moldovan citizens from America voted overwhelmingly (92.82\%) for Maia Sandu, as did those from European countries (92.43\%). A big majority of Moldovans living in Asian countries preferred Maia Sandu (85.71\%), and more than a half of Moldovan migrants living in Middle East also voted for her (59.32\%). Only Moldovan citizens living in former Soviet Union countries voted preponderantly for Igor Dodon 85.91\%. The Moldovans from Middle East showed some support for Dodon (40.68\%), and less from Asian countries (14.29\%). Support for Dodon from European countries and America was only in single digits (Europe - 7.57\%, America - 7.18\%).
The results of the overall vote and the migrant vote show a reverse pattern of the 2016 presidential elections in the Republic of Moldova. Maia Sandu received an overwhelming support from abroad, and more than nine out of ten Moldovans living in America and in European countries supported her. However, voters in Moldova went with Dodon, who became the President of Moldova.

\section{DETERMINANTS OF MOLDOVAN MIGRANT VOTING PREFERENCES}

The study was set to test the hypothesis which of the 1) political realities, as political freedom, civil liberties and political rights, as well as political system and orientation of the 
government are; and 2) the economic realities, as economic freedom and economic development are more projecting more influence on the voting preferences of diaspora. The case study was set to analyze the voting preferences of Moldovan citizens abroad in the Moldovan parliamentary 2014 elections.

The study introduced a number of independent variables to test their relevance to the voting preferences of Moldovan migrants. The research included institutional, political and socio-economic indicators of the countries, where Moldovan diaspora cast their votes. The political variables were the extent of democracy, as measured by the Freedom House indexes of freedom, civil liberties and political rights. The nature of political environment was measured by the variables of political system and orientation of the government.

The analysis included, as well, the indicators of economic freedom, as reported by the Heritage Foundation Economic Freedom. The indicators as size of the government: expenditure, taxes and enterprise, legal structure and security of property rights, access to sound money, freedom to exchange with foreigners, regulation of credit, and labor and business were included as well. And the GDP per capita was included to measure economic development of the host countries.

The results obtained from examining the influence of the various political and economic variables on party support are mixed, but consistent. The numbers reveal that freedom index factor is significantly related to support for the Party of Socialists of Moldova (PSM). (See Appendix, Table 3.) As the freedom index increases, that is, as the index moves from countries designated as free to ones that are designated as less free, vote support increases for the PSM. Civil liberties and political rights are also significant in the vote for the PSM, but less so. In the end, the PSM received more support from Moldovans residing in countries with fewer freedoms. The results also show some correlation with political factors. The nature of the political system was related to voting for the PSM.

Measures of economic freedoms are also influential variables. For instance, the less economic freedom country has, the more likely the voters will support the PSM. Foreign Trade Freedom and the Legal Structure and Security of Property Rights are significantly related to voting for Socialists. Finally, inflation was statistically significant when it came to voting for the Party of Socialists of Moldova.

The same trend of correlations, although less strong, were found between the Party of Communist of Moldova voters and the analyzed variables. (See Appendix, Table 4.) Significant correlations were found related to the political freedom, and particularly civil liberties. The less political freedom and civil liberty the country has, the more inclined are those living in those country to vote for the Communists. The results also show some correlation with the political system, although not on the same magnitude as in the case of political freedom.

The results obtained with the various economic freedom and various sub-indexes are mixed but show some similarities with the case of the Party of Socialists of Moldova. Most notably, the migrants in countries with less pervasive regulation are more likely to vote in favor of the Party of Communists of Moldova. The results show strong correlation with the legal structure and security of property rights; as well as regulation of credit, labor and business; and foreign trade freedom variables. The indicators of economic development seems to not have a direct impact, except the variable of inflation, which shows significant correlation with the voters for the Party of Communists of Moldova.

In comparison with the left-wing political parties, the study found that there are no strong correlations between political freedom and socio-economic variables and the voters for the centrist and centrist-right parties. (See Appendix, Tables 5 and Table 6.) There are not noticeable preferences in either political freedom, or in economic freedom among the voters of the Democratic Party of Moldova, as well as Liberal Democratic Party of Moldova. The results show the voters for those parties are coming from all the countries, without strong preferences for the political freedom or socioeconomic strictures.

However the study shows opposite results for the right-wing Liberal Party of Moldova. (See 
Appendix, Table 7.) The numbers show strong correlation with democracy variables, and political freedom, as those are the most influential measurement. The same results are for the civil liberties and political rights, although the effect is smaller. Supporters of the Liberal Party are actively aware of the political freedom and civil liberties and are coming from the countries where those values are highly regarded. The political environment is less of the determinant, although some correlation is evident between the political system variable and the PL voters.

The results obtained regarding the measures of economic freedom show strong correlations with the Liberal voters. For example, the economic freedom appears to be significant, as well other sub-categories, such as legal structure and security of property rights; foreign trade freedom and regulation of credit; labor and business. The variables for the size of government and access to sound money do not show a relevant influence. The measures of economic development are not significant, as well, with the exception of the inflation variable.

\section{DISCUSSION}

The study analyses the voting preferences of Moldovan migrants who participated in the 2014 parliamentary elections by casting their votes from abroad. The voting preferences of Moldovan diaspora differ substantially from those cast by their compatriots at home. Those results are in line with the preferences of other members of diaspora who participated in their country's national elections by casting their votes from abroad. The voting preferences of Czech and Polish migrants who voted abroad differed substantially from that of their compatriots at home (Fidrmuc \& Doyle, 2004).

The analysis of the voting preferences of diaspora raises the question of self-selection of the countries of destination, as voters possibly selecting the country to migrate according to expectations of their life style, personal wellbeing, professional accomplishments and, as well, political and economic environment in the countries. Although this issue could be addressed for the Moldovan diaspora as well, taking in consideration the voting preferences of
Moldovans living in different countries, moreover the previous research did not confirm such correlation. (Avato, 2009). The public opinion polls are showing, that the Moldovans' decision to migrate is mostly related to the existence of social network between the people decided to migrate and those already living abroad. The previous studies show that those liaisons work in the Former Soviet countries, as well as in the European Union states. (World Bank, 2010). The studies did not find that migration pressure, or intent to migrate to be subject to any self-selection.

The present study found that the political variables, and particularly political freedom and civil liberties are significant factors to influence voting preferences of diaspora members voting for the right and left-wing parties. The political environment, as political system and orientation of the government are less of determinates in voters' preferences, although some correlations are evident, but not on the same magnitude.

The study found that economic variable plays a role in the voting decision of the migrant voters, in case they were aware also of the political freedom. The explanation can lie in the high correlation between the political and economic variables, as well as the specifics of Moldovan diaspora, which are well connected economically to the home county, sending remittances and financially assisting the family members left behind. Also, inflation is another variable, which is significant in this case. The inflation variable could be understood as the important motivator for the migrant workers, as they are aware of the obligation to earn money to support their family members in Moldova. The literature regarding the voting behavior describes that typically voters punish the government for bad economic performance by voting for the opposition, and reward good performance by reelecting the government. But in case of the migrants' votes in the elections in the country of provenience, they are little affected by the economic conditions of that country. The host county economic performance has tangential relevance for their decision to vote in the country of origin, as the better future for their country of birth.

These findings further our understanding of how changes in voters' social and institutional 
environment have an impact over their voting preferences. The scores are mixed, although show that voters tend to adopt the values and norms of their current countries of residence, and this affects their voting preferences. The results are significant for the right and left wing parties, but not for the centrist parties.

\section{CONCLUSION}

This paper analyzed the range of potential determinants, as political and economic realities of the host countries are influencing the voting preferences of Moldovan diaspora. The results are showing that the right-wing parties tend to fare well, and left-wing parties poorly among diaspora members living in democratic countries. The left-wing parties are receiving support from the not-so-democratic former Soviet Union countries.

The results show that the political environment is of relevance for the voters of the right- and left-wing parties and have less impact on the migrants which cast their votes for centrist parties. The right and left wing party supporters are strongly aware of the political freedom, civil liberties and political rights in their host societies, and are residing in countries where those values are respected. The members of Moldovan diaspora, living in the countries with less political liberties and freedoms, are predominantly voting for Party of Socialists and the Party of Communists. The results regarding political environment are not so significant, showing that the political system and the orientation of the government do not play much of a role.

The results regarding the measures of economic freedom and economic development reveal some interesting findings. The supporters of the right- and left-wing parties, which valued political freedom, regarded the economic freedom as well. And for members of diaspora, which voted for centrist parties, the economic component did not matter that much.

This study sets the beginning of analysis of the Moldovan diaspora's members voting preferences in the country of origin. Additional research could further determine other aspects of the migrants' voting behavior. The factors of age, length of time in the host country should be taken in consideration when designing further research. For the case study of Moldovan's diaspora voting preferences, the factor of ethnical identification might play a significant role in elections, and should be taken in consideration, as well.

\section{REFERENCES}

Almond, G. A. and James S. Coleman, eds. (1960). The Politics of the Developing Areas. - Princeton, NJ: Princeton University Press.

Arvizu, J. R., and F.C. Garcia. (1996). Latino voting participation: Explaining and differentiating Latino voting turnout. Hispanic Journal of Behavioral Science.18, pp. 104-28. Ramakrishan, S. J., and T.J. Espenshade. (2001). Immigrant incorporation and political participation in the United States.

International Migration Review 35, pp. 870909.

Avato, J. (2009). Migrattion Pressures and Immigration Polities: New Evidence on the Selection of Migrants. The World Bank. Social protection \& Labor. SP Discussion Paper. 0930: p. 69.

Bauböck R. (2007). Stakeholder Citizenship and Transnational Political Participation: A Normative Evaluation of External Voting. Fordham Law Review, 75 (5): pp. 23932447.

Black H., Richard G. N. and G. Bingham P. (1987). Age, resistance, and political learning in a new environment: The case of Canadian immigrants. Comparative Politics. 20,73-84.

Burgers, Katrina. (2014). Unpacking the Diaspora Channel in the New Democracies: When Do Migrants Act Politically Back Home? Studies in Comparative International Development, 49: pp. 13-43.

Camp R. (2003). Learning Democracy in Mexico and the United States. Mexican Studies, 19(1): 3-27.

Cho, Wendy K.T. (1999) Naturalization, socialization, participation: immigrants and (non-) voting. The Journal Of Politics, 61(4): pp. 1140-55.

Collyer, M. A (2014). Geography of Extraterritorial Citizenship: Explanations of 
External Voting. Migration Studies, 2: pp. 5572.

Conover, P. J., (1991). Political Socialization: Where's the Politics? // Political Science: Looking to the Future. Volume III, Political Behavior, ed. William Crotty. -Evanston, IL: Northwestern University Press.

De la Garza, R.O., Yetim, M. (2003). The Impact of Ethnicity and Socialization on Definitions of Democracy: The Case of Americans and Mexicans. Mexican Studies. 19(1): pp. 81104.

Elster J. (1991).When rationality fails. In: K. S. Cook \& M. Levi, eds. The limits of rationality. - (p. 19-50). Chicago: University of Chicago Press.

Fidrmuc J and Doyle O. (2004). Voice from Diaspora: An Analysis of Migrant Voting Behavior. - William Davidson Institute Working Paper N.712.

Glaser J M. and Gilens M. (1997). Interregional migration and political resocialization. Public Opinion Quarterly, 61: pp. 72-86.

Hahn, C. L., (1998). Becoming Political. Albany: State University of New York Press, 1998.

Harsanyi J. (1969). Rational-Choice Models of Political Behavior vs. Functionalist and Conformist Theories. World Politics, 21(4): pp. 513-538.

Homans, G. (1961). Social Behavior: Its Elementary Forms. - London: Routledge and Kegan Paul.

Lafleur J-M. (2011). Why do states enfranchise citizen abroad? Comparative insights from Mexico, Italy and Belgium. Global Networks, 11(4): pp. 481-501.

Nanestad P. and Paldam Martin (1994). The VPfunction: A Survey of Literature on Vote and Popularity Functions after 25 Years. Public Choice, 79: pp. 213-245.

Neimi, R,G., G.B.Powell Jr., H.W. Stanley, and C.L. Evans. (1985). Testing the converse partisanship model with new electorates. Comparative Political Studies, 18: pp. 300-22.

Neimi, R.G., and J.D.Barkan. (1987). Age and turnout in new electorates and peasant societies. American Political Science Review,
81: pp. 583-88.

Niemi, R. G. and Hepburn A., (1995). The Rebirth of Political Socialization. Perspectives on Political Science, 24:7-16.

OSCE/ODIHR. Republic of Moldova. Parliamentary Elections 30 November 2014. OSCE/ ODIHR Elections Observation Mission Final Report. - Warsaw. March 10, 2015.

http://www.osce.org/odihr/elections/moldova/ 144196?download=true. Last accessed on November 30, 2017.

Ostergaard-Nielsen E. (2001). The Politics of Migrants' Transnational Political Practices. Paper given to the conference on Transnational Migration: Comparative Perspectives. Princeton University.

Ramakrishnan K. and Thomas Espenshade. (2001). Immigration Incorporation and Political Participation in the United States. The International Migration Review. 35 (3): pp. 870-909.

Rhodes S. \& Hatutyunyan A. (2010). Extending Citizenship to Emigrants: Democratic Contestation and a New Global Norm. International Political Science Review, 31: pp. 470-490.

Turku, A. Diffusion of Diaspora Enfranchisement Norms: A Multinational Study. //Comparative Political Studies, vol. 48, issue 4, 2015, pp. 407-437.

UN in Moldova. (2017). Making the most of migration in Moldova. At http://md.one.un.org/content/unct/moldova/en /home/presscenter/stories/making-the-mostof-migration-in-moldova.html. Last accessed on November 30, 2018.

Wong, Janells S. (2000). The effects of age and political exposure on the development of party identification among Asian American and Latino immigrants in the United States. Political Behavior.

Word Bank. (2010). Strengthening the link between migration and development in Moldova. Chisinau. p. 57. http://siteresources.worldbank.org/INTMOLD OVA/Resources/ConsolidareaLegaturiiDintre MigratieDezvoltare.pdf 


\section{Appendix:}

Table 3. Party of Socialists of Moldova: General to Specific Results

\begin{tabular}{|c|c|c|c|}
\hline Variables & Results & Constant & R-squared \\
\hline \multicolumn{4}{|l|}{ Measure of Democracy } \\
\hline \multirow[t]{2}{*}{ Free/Partially Free/Not free } & $12.41^{* * *}$ & -6.236 & 0.407 \\
\hline & $(2.828)$ & $(4.501)$ & \\
\hline \multirow[t]{2}{*}{ Civil Liberties } & $5.294^{* * *}$ & 0.0154 & 0.383 \\
\hline & $(1.271)$ & $(3.450)$ & \\
\hline \multirow[t]{2}{*}{ Political Rights } & $4.251^{* * *}$ & 1.923 & 0.34 \\
\hline & $(1.120)$ & $(3.317)$ & \\
\hline \multicolumn{4}{|l|}{ Measures of Political Environment } \\
\hline \multirow[t]{2}{*}{ Political System } & $-6.216^{* *}$ & $19.42^{* * *}$ & 0.147 \\
\hline & $(2.834)$ & $(4.569)$ & \\
\hline \multirow[t]{2}{*}{ Orientation of the Government } & -2.214 & $14.31^{* * *}$ & 0.028 \\
\hline & $(2.457)$ & $(4.463)$ & \\
\hline \multicolumn{4}{|l|}{ Measures of Economic Freedom } \\
\hline \multirow[t]{2}{*}{ Economic Freedom } & $-0.864^{* * *}$ & $68.92^{* * *}$ & 0.282 \\
\hline & $(0.260)$ & $(17.57)$ & \\
\hline \multirow[t]{2}{*}{ Size of Government } & 4.286 & -13.79 & 0.085 \\
\hline & $(2.713)$ & $(15.64)$ & \\
\hline \multirow[t]{2}{*}{ Legal Structure and Security of Property Rights } & $-7.504^{* * *}$ & $61.70^{* * *}$ & 0.277 \\
\hline & $(2.332)$ & $(16.07)$ & \\
\hline \multirow[t]{2}{*}{ Access to Sound Money } & 0.000174 & $10.81^{* * *}$ & 0.004 \\
\hline & $(0.000506)$ & $(2.910)$ & \\
\hline \multirow[t]{2}{*}{ Foreign Trade Freedom } & $-14.84^{* * *}$ & $127.1^{* * *}$ & 0.485 \\
\hline & $(2.942)$ & $(23.19)$ & \\
\hline \multirow[t]{2}{*}{ Regulation of Credit, Labor and Business } & $-10.27^{* *}$ & $86.16^{* *}$ & 0.151 \\
\hline & $(4.693)$ & $(34.64)$ & \\
\hline \multicolumn{4}{|l|}{ Measures of Economic Development } \\
\hline \multirow[t]{2}{*}{ GDP per capita } & $2.11 \mathrm{e}-06$ & $10.78^{* * *}$ & 0.004 \\
\hline & $(6.33 e-06)$ & $(2.971)$ & \\
\hline \multirow[t]{2}{*}{ GDP Growth Rate } & -0.909 & $13.27^{* * *}$ & 0.023 \\
\hline & $(1.124)$ & $(3.813)$ & \\
\hline \multirow[t]{2}{*}{ Inflation } & $2.329^{* * *}$ & $6.136^{* *}$ & 0.425 \\
\hline & $(0.512)$ & $(2.378)$ & \\
\hline \multicolumn{4}{|l|}{ Standard errors in parentheses } \\
\hline${ }^{* * *} \mathrm{p}<0.01,{ }^{* *} \mathrm{p}<0.05,{ }^{*} \mathrm{p}<0.1$ & & & \\
\hline
\end{tabular}


Table 4. Party of Communists of Moldova: General to Specific Results

\begin{tabular}{|c|c|c|c|}
\hline Variables & Results & Constant & R-squared \\
\hline \multicolumn{4}{|l|}{ Measure of Democracy } \\
\hline \multirow[t]{2}{*}{ Free/partially free/Not free } & $2.884^{* *}$ & 2.829 & 0.145 \\
\hline & $(1.326)$ & $(2.110)$ & \\
\hline \multirow[t]{2}{*}{ Civil Liberties } & $1.549^{* * *}$ & $3.614^{* *}$ & 0.215 \\
\hline & $(0.559)$ & $(1.518)$ & \\
\hline \multirow[t]{2}{*}{ Political Rights } & $1.020^{*}$ & $4.656^{* * *}$ & 0.129 \\
\hline & $(0.502)$ & $(1.487)$ & \\
\hline \multicolumn{4}{|l|}{ Measures of Political Environment } \\
\hline \multirow[t]{2}{*}{ Political system } & -1.041 & $8.254^{* * *}$ & 0.027 \\
\hline & $(1.181)$ & $(1.904)$ & \\
\hline \multirow[t]{2}{*}{ Orientation of the Government } & -0.783 & $7.989^{* * *}$ & 0.023 \\
\hline & $(0.961)$ & $(1.746)$ & \\
\hline \multicolumn{4}{|l|}{ Measures of Economic Freedom } \\
\hline \multirow[t]{2}{*}{ Economic Freedom } & $-0.291^{* *}$ & $26.32^{* * *}$ & 0.023 \\
\hline & $(0.107)$ & $(7.191)$ & \\
\hline \multirow[t]{2}{*}{ Size of Government } & 1.389 & -1.267 & 0.059 \\
\hline & $(1.069)$ & $(6.163)$ & \\
\hline \multirow[t]{2}{*}{ Legal Structure and Security of Property Rights } & $-3.430^{* * *}$ & $30.00^{* * *}$ & 0.384 \\
\hline & $(0.837)$ & $(5.768)$ & \\
\hline \multirow[t]{2}{*}{ Access to Sound Money } & 0.000177 & $6.887^{* * *}$ & 0.030 \\
\hline & $(0.000194)$ & $(1.116)$ & \\
\hline \multirow[t]{2}{*}{ Foreign Trade Freedom } & $-3.880^{* *}$ & $37.09^{* * *}$ & 0.220 \\
\hline & $(1.407)$ & $(11.09)$ & \\
\hline \multirow[t]{2}{*}{ Regulation of Credit, Labor and Business } & $-3.796^{* *}$ & $34.56^{* *}$ & 0.136 \\
\hline & $(1.839)$ & $(13.57)$ & \\
\hline \multicolumn{4}{|l|}{ Measures of Economic Development } \\
\hline \multirow[t]{2}{*}{ GDP per capita } & $1.98 \mathrm{e}-06$ & $6.535^{* * *}$ & 0.023 \\
\hline & $(2.45 \mathrm{e}-06)$ & $(1.148)$ & \\
\hline \multirow[t]{2}{*}{ GDP Growth Rate } & -0.335 & $7.653^{* * *}$ & 0.020 \\
\hline & $(0.439)$ & $(1.490)$ & \\
\hline \multirow[t]{2}{*}{ Inflation } & $0.658^{* * *}$ & $5.456^{* * *}$ & 0.223 \\
\hline & $(0.232)$ & $(1.079)$ & \\
\hline \multicolumn{4}{|l|}{ Standard errors in parentheses } \\
\hline${ }^{* * *} \mathrm{p}<0.01,{ }^{* *} \mathrm{p}<0.05,{ }^{*} \mathrm{p}<0.1$ & & & \\
\hline
\end{tabular}


Table 5. Democratic Party of Moldova: General to Specific Results

\begin{tabular}{|c|c|c|c|}
\hline Variables & Results & Constant & R-squared \\
\hline \multicolumn{4}{|l|}{ Measure of Democracy } \\
\hline \multirow[t]{2}{*}{ Free/Partially Free/Not free } & -2.023 & $15.23^{* * *}$ & 0.068 \\
\hline & $(1.418)$ & $(2.257)$ & \\
\hline \multirow[t]{2}{*}{ Civil Liberties } & -0.791 & $14.06^{* * *}$ & 0.053 \\
\hline & $(0.629)$ & $(1.708)$ & \\
\hline \multirow[t]{2}{*}{ Political Rights } & -0.729 & $13.98^{* * *}$ & 0.062 \\
\hline & $(0.534)$ & $(1.580)$ & \\
\hline \multicolumn{4}{|l|}{ Measures of Political Environment } \\
\hline \multirow[t]{2}{*}{ Political System } & -0.203 & $12.67^{* * *}$ & 0.001 \\
\hline & $(1.226)$ & $(1.977)$ & \\
\hline \multirow[t]{2}{*}{ Orientation of the Government } & -0.326 & $12.87^{* * *}$ & 0.004 \\
\hline & $(0.995)$ & $(1.807)$ & \\
\hline \multicolumn{4}{|l|}{ Measures of Economic Freedom } \\
\hline \multirow[t]{2}{*}{ Economic Freedom } & 0.0106 & 11.69 & 0.000 \\
\hline & $(0.123)$ & $(8.291)$ & \\
\hline \multirow[t]{2}{*}{ Size of Government } & -1.137 & $18.91^{* * *}$ & 0.036 \\
\hline & $(1.139)$ & $(6.564)$ & \\
\hline \multirow[t]{2}{*}{ Legal Structure and Security of Property Rights } & -0.863 & $18.33^{* *}$ & 0.022 \\
\hline & $(1.109)$ & $(7.645)$ & \\
\hline \multirow[t]{2}{*}{ Access to Sound Money } & -0.000248 & $12.08^{* * *}$ & 0.053 \\
\hline & $(0.000202)$ & $(1.160)$ & \\
\hline \multirow[t]{2}{*}{ Foreign Trade Freedom } & 2.303 & -5.638 & 0.070 \\
\hline & $(1.617)$ & $(12.74)$ & \\
\hline \multirow[t]{2}{*}{ Regulation of Credit, Labor and Business } & 0.921 & 5.667 & 0.007 \\
\hline & $(2.074)$ & $(15.31)$ & \\
\hline \multicolumn{4}{|l|}{ Measures of Economic Development } \\
\hline \multirow[t]{2}{*}{ GDP per capita } & $4.12 \mathrm{e}-07$ & $12.33^{* * *}$ & 0.001 \\
\hline & $(2.53 e-06)$ & $(1.190)$ & \\
\hline \multirow[t]{2}{*}{ GDP Growth Rate } & -0.102 & $12.64^{* * *}$ & 0.002 \\
\hline & $(0.454)$ & $(1.541)$ & \\
\hline \multirow[t]{2}{*}{ Inflation } & -0.384 & $13.22^{* * *}$ & 0.072 \\
\hline & $(0.260)$ & $(1.208)$ & \\
\hline \multicolumn{4}{|l|}{ Standard errors in parentheses } \\
\hline${ }^{* * *} \mathrm{p}<0.01,{ }^{* *} \mathrm{p}<0.05,{ }^{*} \mathrm{p}<0.1$ & & & \\
\hline
\end{tabular}


Table 6. Liberal Democratic Party of Moldova: General to Specific Results

\begin{tabular}{|c|c|c|c|}
\hline Variables & Results & Constant & R-squared \\
\hline \multicolumn{4}{|l|}{ Measure of Democracy } \\
\hline \multirow[t]{2}{*}{ Free/Partially Free/Not free } & -2.907 & $48.40^{* * *}$ & 0.031 \\
\hline & $(3.080)$ & $(4.903)$ & \\
\hline \multirow[t]{2}{*}{ Civil Liberties } & -1.150 & $46.75^{* * *}$ & 0.025 \\
\hline & $(1.361)$ & $(3.693)$ & \\
\hline \multirow[t]{2}{*}{ Political Rights } & -0.677 & $45.80^{* * *}$ & 0.012 \\
\hline & $(1.167)$ & $(3.455)$ & \\
\hline \multicolumn{4}{|l|}{ Measures of Political Environment } \\
\hline \multirow{2}{*}{ Political System } & 2.865 & $40.51^{* * *}$ & 0.043 \\
\hline & $(2.556)$ & $(4.121)$ & \\
\hline \multirow[t]{2}{*}{ Orientation of the Government } & 2.865 & $40.51^{* * *}$ & 0.043 \\
\hline & $(2.556)$ & $(4.121)$ & \\
\hline \multicolumn{4}{|l|}{ Measures of Economic Freedom } \\
\hline \multirow[t]{2}{*}{ Economic Freedom } & -2.907 & $48.40^{* * *}$ & 0.031 \\
\hline & $(3.080)$ & $(4.903)$ & \\
\hline \multirow[t]{2}{*}{ Size of Government } & $-4.182^{*}$ & $68.13^{* * *}$ & 0.106 \\
\hline & $(2.337)$ & $(13.47)$ & \\
\hline \multirow[t]{2}{*}{ Legal Structure and Security of Property Rights } & 3.265 & 22.12 & 0.069 \\
\hline & $(2.306)$ & $(15.90)$ & \\
\hline \multirow[t]{2}{*}{ Access to Sound Money } & -0.000251 & $44.00^{* * *}$ & 0.012 \\
\hline & $(0.000439)$ & $(2.526)$ & \\
\hline \multirow[t]{2}{*}{ Foreign Trade Freedom } & $6.897^{* *}$ & -9.780 & 0.138 \\
\hline & $(3.318)$ & $(26.15)$ & \\
\hline \multirow[t]{2}{*}{ Regulation of Credit, Labor and Business } & -0.0535 & 44.77 & 0.000 \\
\hline & $(4.438)$ & $(32.76)$ & \\
\hline \multicolumn{4}{|l|}{ Measures of Economic Development } \\
\hline \multirow[t]{2}{*}{ GDP per capita } & $-9.67 e-07$ & $44.49^{* * *}$ & 0.001 \\
\hline & $(5.40 \mathrm{e}-06)$ & $(2.534)$ & \\
\hline \multirow[t]{2}{*}{ GDP Growth Rate } & 0.948 & $42.11^{* * *}$ & 0.034 \\
\hline & $(0.952)$ & $(3.228)$ & \\
\hline \multirow[t]{2}{*}{ Inflation } & $-1.118^{* *}$ & $46.73^{* * *}$ & 0.135 \\
\hline & $(0.535)$ & $(2.484)$ & \\
\hline \multicolumn{4}{|l|}{ Standard errors in parentheses } \\
\hline${ }^{* * *} \mathrm{p}<0.01,{ }^{* *} \mathrm{p}<0.05,^{*} \mathrm{p}<0.1$ & & & \\
\hline
\end{tabular}


Table 7. Liberal Party of Moldova: General to Specific Results

\begin{tabular}{|c|c|c|c|}
\hline Variables & Results & Constant & R-squared \\
\hline \multicolumn{4}{|l|}{ Measure of Democracy } \\
\hline \multirow[t]{2}{*}{ Free/Partially Free/Not free } & $-10.45^{* * *}$ & $40.20^{* * *}$ & 0.441 \\
\hline & $(2.222)$ & $(3.537)$ & \\
\hline \multirow[t]{2}{*}{ Civil Liberties } & $-4.856^{* * *}$ & $35.76^{* * *}$ & 0.491 \\
\hline & $(0.934)$ & $(2.535)$ & \\
\hline \multirow[t]{2}{*}{ Political Rights } & $-3.846^{* * *}$ & $33.90^{* * *}$ & 0.424 \\
\hline & $(0.846)$ & $(2.506)$ & \\
\hline \multicolumn{4}{|c|}{ Measures of Political Environment } \\
\hline \multirow[t]{2}{*}{ Political System } & $4.757^{* *}$ & $19.22^{* * *}$ & 0.131 \\
\hline & $(2.314)$ & $(3.732)$ & \\
\hline \multirow[t]{2}{*}{ Orientation of the Government } & 1.034 & $24.08^{* * *}$ & 0.009 \\
\hline & $(2.008)$ & $(3.647)$ & \\
\hline \multicolumn{4}{|l|}{ Measures of Economic Freedom } \\
\hline \multirow[t]{2}{*}{ Economic Freedom } & $1.009^{* * *}$ & $-41.96^{* * *}$ & 0.589 \\
\hline & $(0.159)$ & $(10.76)$ & \\
\hline \multirow[t]{2}{*}{ Size of Government } & 0.117 & $25.64^{*}$ & 0.000 \\
\hline & $(2.212)$ & $(12.75)$ & \\
\hline \multirow[t]{2}{*}{$\begin{array}{l}\text { Legal Structure and Security of } \\
\text { Property Rights }\end{array}$} & $8.278^{* * *}$ & $-30.12^{* * *}$ & 0.554 \\
\hline & $(1.428)$ & $(9.846)$ & \\
\hline \multirow[t]{2}{*}{ Access to Sound Money } & 0.000211 & $26.63^{* * *}$ & 0.011 \\
\hline & $(0.000393)$ & $(2.263)$ & \\
\hline \multirow[t]{2}{*}{ Foreign Trade Freedom } & $9.654^{* * *}$ & $-49.50^{* *}$ & 0.337 \\
\hline & $(2.604)$ & $(20.52)$ & \\
\hline \multirow[t]{2}{*}{$\begin{array}{l}\text { Regulation of Credit, Labor and } \\
\text { Business }\end{array}$} & $13.48^{* * *}$ & $-72.94^{* * *}$ & 0.427 \\
\hline & $(3.008)$ & $(22.20)$ & \\
\hline \multicolumn{4}{|c|}{ Measures of Economic Development } \\
\hline \multirow[t]{2}{*}{ GDP per capita } & $-3.75 e-06$ & $26.19^{* * *}$ & 0.019 \\
\hline & $(5.08 \mathrm{e}-06)$ & $(2.386)$ & \\
\hline \multirow[t]{2}{*}{ GDP Growth Rate } & 0.452 & $24.51^{* * *}$ & 0.009 \\
\hline & $(0.917)$ & $(3.108)$ & \\
\hline \multirow[t]{2}{*}{ Inflation } & $-1.499^{* * *}$ & $28.78^{* * *}$ & 0.269 \\
\hline & $(0.467)$ & $(2.171)$ & \\
\hline \multicolumn{4}{|l|}{ Standard errors in parentheses } \\
\hline${ }^{* * *} p<0.01,{ }^{* *} p<0.05,{ }^{*} p<0.1$ & & & \\
\hline
\end{tabular}


List of Explanatory Variables:

\section{Measure of Democracy}

Freedom House Democracy Index.

Coded as: Free- $1 /$ partially free- 2 /

not free- 3.

- Civil Liberties. Coded as: 1- most

free, 7- least free.

- Political Rights. Coded as: 1- most free, 7- least free.

\section{Measures of Political Environment}

Political System. Coded as: 0presidential; 1 -assambly elected president; 2-parliamentary, 3communist state)

$\square$ Political orientation of the current government. Coded as: 1-right; 2 center; 3-left; 0-no info; NA-no executive.

\section{Measures of Economic Freedom}

Heritage Foundation Economic Freedom Index Coded as: free -80100 ; mostly free $-70.0-$

79.9; moderately free -60.0-69.9; mostly unfree - 50.0-59.9; repressed 0-49.9.

- Sub-indexes of Eraser Economic Freedom: Coded as: scaled from 0 not free to 10 - the most free

- $\quad$ Size of the Government: Expenditure, Taxes and Enterprise

- Legal Structure and Security of Property Rights

- $\quad$ Access to Sound Money

- Freedom to exchange with foreigners

- Regulation of Credit, Labor and Business
GDP Growth: Gross Domestic Product growth is in percent as of 2014 and 2016;

Inflation: Inflation is in the GDP deflator (annual \%), as of 2014 and 2016.

\section{ABOUT THE AUTHOR}

Alla Rosca, email: allarosca24@gmail.com

Dr. Alla Rosca is the Associate Researcher at Edgewater Research LLC in New Orleans, LA, USA. Previously Alla Rosca taught at Tulane University, New Orleans, USA and was the Full Professor at International Relations and Political Science Department at Moldova State University. Dr. Rosca is one of the founding members of the Information and Documentation Center on NATO in Moldova. She has been a Visiting Professor at Rutgers University, USA, Bucharest University, Romania, and Oxford University, UK. In addition, she was awarded with a research scholarship from the Fulbright Project, USA in 2007-2008. Dr. Rosca published two books and more than fifty scientific articles in various academic journals around the world.

\section{Measures of Economic Development} GDP per capita: Gross Domestic Product is in per capita terms at purchasing power parity and in thousands of current US\$ as of 2014 and 2016; 